While speaking of entomological matters, allow me to mentioal that in the month of August last year the small blue lobelias in my garden were the favourite resort not only of my hive-bees, but of a species of wild bee so singularly resembling them in every respect (excepting, perhaps, a barely perceptible amount of greater firmness and roundness of form), that they could only be distinguished by the presence of a tuft of lemon-yellow hairs in the front of the head between the eyes. I thought at first that this might have resulted from a lodgment of pollen, but it soon became evident that it was a specific distinction. These pretty insects were very numerous, but I never found any nest. Will some apiarian reader oblige me with an identification?

To turn to a somewhat different subject. In a little book called "Flowers of the Year," published by the Religious Tract Society, is the following passage : "An interesting phenomenon is sometimes exhibited by red and orange-coloured flowers, and also, in a less degree, by yellow-tinted blossoms. It is that of a light of their own colour playing about the plant. This is not the result of an inflammable vapour igniting on the approach of a candle, but seems rather, as Sharon Turner has remarked, 'an actual secretion of light additional to their usual show.' The cause of this phenomenon has not been discovered, but it seems dependent on an electrical state of the atmosphere. It has not been seen during the bright sunshine, but has been ob. served after sunset in several flowers, as the marigold, the different species of poppy, the scarlet geranium, and even in the heartsease" I have several times met with a similar statement, and much wish to know what trust worthy foundation there may be for it. I have repeatedly tried to verify it by observation, but in vain.

Since penning the above remarks, the yellow-visored bee has again appeared on the blossoms of a Linaria Alpina, the descendant of a plant brought by my wife from Switzerland seven years ago, and now blooming profusely with us. I have seen several specimens of my old friend, but camnot as yet satisfy myself that the yellow tint is due to hair of that colour, as I supposed last year.

Hardwick Vicarage, July I2

T. W. WEBB

\section{The Solar Spots}

I HAVE been much interested of late in observing the solar spots, and especially in the greatly-increased numbers which have lately made their appearance. I have counted from too to 200 spots, through a six-feet telescope, with a power of 100 , quite frequently in the past few months. On the 22nd ult., with a power of 200, I counted 675 sun spots, and on the 27 th saw 470 with the 100 eyepiece. In general, I think the number of spots visible is about in proportion to the power used when the atmosphere is favourable for high powers. During the month several spots were visible to the naked eye.

I feel quite desirous to learn what our spectroscopists find about the sun's margin, also if observations indicate a terrestrial magnetic force corresponding with the sun's activity.

Would not many readers of NATURS be much interested with rèsults from Huggins and Lockyer and the Kew observers?

Spiceland, Indiana, July 6

W. DAWSON

\section{DARWIN BEFORE THE FRENCH ACADEMY}

THE discussion on the claims of Mr. Darwin for elec$I$ tion into the Zoological Section of the Paris Academy was continued at the meeting on August $r$ in comité secret, and the Revue des Cours Scientifiques gives a report, of which the following is an abstract, of $M$. de Quatrefages' brilliant and able reply to M. Blanchard :There are two men included in Mr. Darwin, a naturalist observer and a theoretical thinker : the naturalist is exact, sagacious, and patient ; the thinker is original and penetrating, often just, sometimes too rash. That the theory with which his name is connected, that of Natural Selection, has in it at least something seductive and plausible, is shown by its having been worked out by such men as Darwin, Wallace, and Naudin, labouring independently and in different paths. If the ideas and the works of Darwin are such as some of his opponents represent, how can they have obtained the support in less than ten years of such men as Lyell, Hooker, Huxley, Karl Vogt, Lubbock, Haeckel, Filippi, and Brandt himself, who has just been elected correspondent in opposition to Mr. Darwin? In Darwin's great work there are certainly some things which are found in Lamarck, the laws of heredity, and the transmission and progressive development of characters. The point of departure of Lamarck is an incessant spontaneous generation, that of Darwin is a unique archetype which he supposes to pre-exist, and the origin of which he does not seek. That which belongs to Darwin alone is the laws of variation which he has established, and the law of correlation of growth. His error has been the confusion between the laws which regulate the founda. tion and propagation of races and of species; substitute the former for the latter and his theory is incontrovertible. Without defending Mr. Darwin's theories, some of which he has indeed publicly combated, M. de Quatrefages then proceeded to enumerate the various branches of scientific inquiry in which $\mathrm{Mr}$. Darwin has made original observations, and concerning which he has contributed works of great importance to science. In geology we find seven great memoirs-I. On coral islands; 2 . Geological observations on volcanic islands; 3. Geological observations in South America; 4. On the connection of the volcanic phenomena in South America ; 5. On the distribution of erratic blocks in South America; 6. On the geology of the Falkland Islands; 7. Origin of the saliferous deposits of Patagonia. In botany the speaker invoked the testimony of Dr. Hooker that the most beatutiful discoveries made during the last ten years in vegetable physiology belong to Mr. Darwin. Finally, in zoological literature we have the report of the voyage of the Beagle; and the monograph of the Cirrhipedes, one of the most important monographs ever published. After speaking of his more popular works on the origin of species and the variation of animals and plants under domestication, $M$. de Quatrefages referred to his important and laborious investigations of the strange variations in fowls, pigeons, and rabbits ; and summed up his eloquent address as follows :-"En résumé, M. Darwin est un naturaliste éminent qui veut écarter de la science l'invocation de la cause première, et chercher l'explication des faits naturels du monde organisé dans les causes secondes, comme on le fait depuis longtemps en géologie, en chimie, en physique. Mais il ne va pas au delà, et il ne faudrait pas juger Darwin sur la parole de quelques disciples qui semblent parfois ne pas avoir lu ses ouvrages. Il y aurait injustice à le rendre responsable des exagérations et des aberrations de ceux qui s'abritent sous son nom."

M. de Quatrefages was followed by M. Ad. Brongniart, who attacked the Darwinian system, denying the existence of variation in plants. The appearance of species is a fact which can only be explained by a supernatural cause, and Darwinism is nothing but a fairy tale. M. Ch. Robin considered that in respect of proved facts which he had introduced into science, there would be a hundred zoologists who should have precedence over Darwin. M. H. Milne-Edwards replied to $M$. Brongniart, that the sea sometimes: discloses fairy tales, and spoke of the very great value of the monograph of the Cirrhipedes. Although himself opposed to Darwinism, he strongly supported his nomination. M. de Quatrefages, in reply, denied the charge against Darwin made by $M$. Blanchard, that he had declared that man was descended from the apes. In deciding Mr. Darwin's claims, we ought not to be influenced by those points in which we have to combat his views, any more than Lamarck was judged in this manner. In spite of his errors, he will be none the less one of the glories of science and of the Academy. His nomination will not make the Academy Darwinian. Men. of science know that the Institute appreciates work independently of doctrine, and men of the world know that the supporters of Darwin in the zoological section, MM. Milne-Edwards, and de Quatrefages, have always professed themselves opposed to his ideas. The discussion was then adjourned to last Monday evening. 